8) G.W. Barr and R.O. Strarman: Aeroelastic stability characteristics of cylindrical shells considering imperfections and edge constraint, AIAA Paper, No. 68-285 (1968).

9) D. A. Evensen and M. D. Olson: Nonlinear fitter of a circular cylindrical shell in supersonic flow, NASA TN D-4265 (1968).

10) D. A. Evensen: Nonlinear flexural vibrations of thin-walled circular cylinders, NASA TN D-4090 (1967).

11）松崎雄嗍：円筒殼の超音速パホルフラッター，東京大 学工学系研究科航空学課程修士論文 (1966-3) の第 I 部.
12）松崎雄哃，小林繁夫：薄肉円筒殻の非線形振動解析， 日本航空宇宙学会誌 Vol. 17, No. 187, pp. 308-315 (1969).

13) Y. MatsuzakI and S. KobayashI: A theoretical and experimental study of the nonlinear flexural vibration of thin circular cylindrical shells with clamped ends, Trans. Japan soc. Aero. Space Sci., 12, 21, pp. 55-62 (1969)

14）松崎雄䏤司，小林繁夫：両端固定円筒殼の超音速パネル フラッターの理論之実驗，日本航空宇宙学会誌 Vol. 17, No. 188, pp. 346-353 (1969).

15) ボゴリューボフ \& ミトロポリスキー：非線形振動諭, 共立出版 (1961).

\title{
板翼の超音速フラッター速度の一計算法*
}

$$
\text { 名 取 通弘**.小林繁 } \text { 夫*** }^{* * *}
$$

\section{A Method to Calculate the Supersonic Flutter Speed of Plate Wings}

\author{
Michihiro Natori and Shigeo KobayashI
}

\begin{abstract}
A method to calculate the supersonic bendingtorsion Hutter speed of cantilever plate wings of low aspect ratio is presented. The deflection mode is assumed in a double power series expansion of spanwise and chordwise variables, and the flutter determinant is derived with the aid of the principle of minimum potential energy of the dynamic problem. The chordwise variable is measured from the midchord line along the stream direction for swept-back wings. For the aerodynamic force, the piston theory including the effect of wing thickness is used. Numerical computation is carried out for a cantilever trapezoid tested at the National Aerospace Laboratory. It has been observed that the ten terms approximation yields a good result in comparison with the twenty terms approximation. It has been clarified that the effect of aerodynamic damping on the flutter speed is very small. Reasonable results are obtained in comparison with the experimental results. Furthermore the present method is extended to cantilever plates partially clamped at the root.
\end{abstract}

\section{1. 序論}

超音速流中の翼のフラッターは，超音速機設計上重 要な問題であるのにもかかわらず公表されている研究 論文は意外に少ない，それば主として軍事機密として

\footnotetext{
* 第 3 節までは昭和 43 年 7 月 6 日第 10 回構造強度に関 する講演会で発表，第 4 節以降は昭和 44 年 7 月 3 日

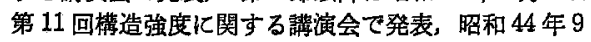
月 19 日原稿受理

** 東京大学大学院工学系研究科航空学専門課程

*** 東京大学工学部航空学科
}

公表を押えられているととによるすのと考えられる. しかし基整的なものは発表されており，H. AsHLEY and G. ZARTARIAN ${ }^{1}$ ( は空気力として piston theory を用いると解析が極めて簡単になるととを示してい る. との piston theory 使用の可否については, H. G Morgan, H. L. Runyan and V. HUCKeL ${ }^{2)}$ が 2 次元 翼について詳しい解析的検討を行ない，マッ八数 2 以 上ではほぼ満足すべき結果を与えるととを示してい る. H. G. MORGAN, V. HuCKeL and H. L. RUNYAN ${ }^{3}$ はアスペクト比の小さい翼に適用出来るよう翼弦の変 形を考慮した解法を示している. E. NAKAI, T. TAKAGI, K. IsOGAI and T. MORITA (4)板巽につい てマッ八数 1.5〜4.0 の範囲で実験的研究を行ない, 固有振動モードについての知識を用いて 3 自由度の問 題として計算した理論值と比較して, 理論値は実験值 よりあフラッター動圧で $30 \%$ 程度高めであるという 結果を示している. E. C. YATES Jr. ${ }^{5}$ はマッ八数 2 ま での翟の実驗之の比較を行ない, piston theory ある いは準定常 second-order theory による理論值が実験 值より $38 \%$ 程度高い事を論じている. 高いマッ八数 の超音速流中のフラッターでは当然空力加熱の影響が 問題になるが，乙の問題については文献 6)９）の研 究が発表されている.

フラッター速度の計算法としては, 固有振動モード についての知識を用いて 2 ないし 3 自由度のフラッタ 一の問題として取扱われる場合が多く, アスペクト比 が大きい場合は実用上適当である. しかし本諭文で取 り上げているロケット尾翼のようにアスペクト比の小 さい板翼の場合は, 固有振動モードについて調べると 
と自体がかなりやっかいなのと，何次の固有振動モー ドまでとれば良いかが不明確なので，本論文では著者 の一人が先に板翼の固有振動解析に用いた方法 ${ }^{102}$ (す なわち midchord line に注目した學級数展開法)を 超音速フラッタ一速度の計算に拡張適用して, 固有振 動モードの知識を必要とするととなく，変分問題の直 接解法によって直接求める方法を提案し, 従来の計算 法による值および E. NAKAI ほがの実験結果と比較 して十分害用性のあることを示す. 空気力のより㛜密 な取り扱いとしては kernel function 法 ${ }^{11}$ 等の数值解 法があげられ，文献 12）にはその概観がのべられてい る. 本論文では計算方法の検討を主にしたので, 空気 力としては，とれまでの多くの研究と同様に piston theoryを用いた.なお本研究の最終的なねらいは空 力加熱によって熱応力が発生した状態でのフラッター 速度の計算法を示すことであるが，本論文はその前段 階として空力加熱のない場合について述べたるのであ 万.

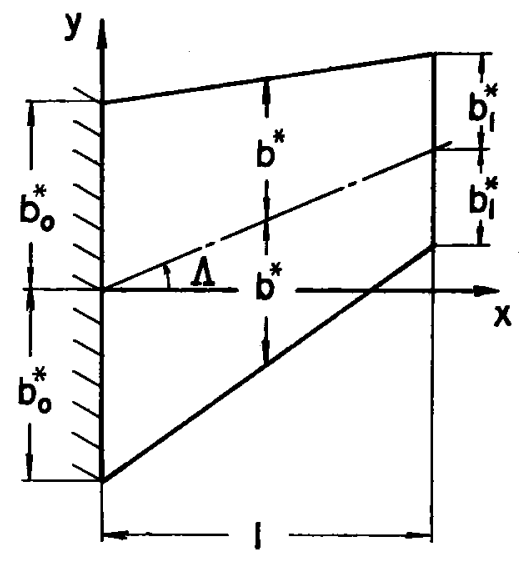

第 1 図 翼平面形

\section{2. 解 析 理 論}

第 1 図のような平面形の等方性変厚片持板を扱う. この系のポテンシャルエネルギー $\Pi^{*}$ を撓み $W$ で変 分したものは

$$
\begin{aligned}
\delta \Pi^{*}= & \delta \iint_{S} \frac{D}{2}\left[\left(\frac{\partial^{2} W}{\partial x^{2}}+\frac{\partial^{2} W}{\partial y^{2}}\right)^{2}-2(1-\nu)\left\{\frac{\partial^{2} W}{\partial x^{2}} \frac{\partial^{2} W}{\partial y^{2}}-\left(\frac{\partial^{2} W}{\partial x \partial y}\right)^{2}\right\}\right] d x d y \\
& -\iint_{S} p \delta W d x d y
\end{aligned}
$$

と表わされる.ととでDは板の曲げ剛性，レはポアッソン比を表わす. 分布荷重 $p$ は, 空気力と慣性力とからなっ ており，空気力としては翼厚の効果まで含めた piston theory を用いるととによって，pは

$$
p=-\frac{\rho_{\infty} U^{2}}{2 M}\left[4+(\gamma+1) M \frac{\partial h^{*}}{\partial y}\right]\left[\frac{\partial W}{\partial y}+\frac{1}{U} \frac{\partial W}{\partial t}\right]-\rho h^{*} \frac{\partial^{2} W}{\partial t^{2}}
$$

と表わされる. ことで $\rho_{\infty}, U, M$ は一様流の密度, 速度, マッ八数， $\gamma$ は空気の比熱比（以下 1.4 とて数値計 算する) $, \rho, h^{*}$ は翼の密度，厚さを表わす. フラッター速度および振動数を求めるのだから，W( $\left.x, y, t\right)$ （は時間 t.について

$$
W(x, y, t)=w(x, y) e^{i \omega t}
$$

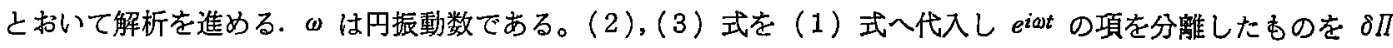
と記すと

$$
\begin{aligned}
\delta I= & \delta \iint_{S} \frac{D}{2}\left[\left(\frac{\partial^{2} w}{\partial x^{2}}+\frac{\partial^{2} w}{\partial y^{2}}\right)^{2}-2(1-\nu)\left\{\frac{\partial^{2} w}{\partial x^{2}} \frac{\partial^{2} w}{\partial y^{2}}-\left(\frac{\partial^{2} w}{\partial x \partial y}\right)^{2}\right\}\right] d x d y \\
& +\iint_{S} \frac{\rho_{\infty} U^{2}}{2 M}\left[4+(\gamma+1) M \frac{\partial h^{*}}{\partial y}\right]\left(\frac{\partial w}{\partial y}+\frac{i \omega}{U} w\right) \delta w d x d y \\
& -\iint_{S} \rho h^{*} \omega^{2} w \delta w d x d y
\end{aligned}
$$

となる。

この片持ち板の境界条件は $x=0$ 辺で固定, 他の 3 辺は自由である. 翼弦中心線からの距離を $z$ として， すなわち $z$ は,

$$
\text { ここで }_{k=\tan \Lambda}^{z=y-k x}
$$

と表わされるが，との $z$ と $x$ にって，撓み形שを幾 何学的境界条件を满足するつきのようなべき級数であ
らわす。

$$
w=\sum_{m=0}^{\infty} \sum_{n=2}^{\infty} a_{m n} * z^{m} x^{n}
$$

$w$ を $x$ と $y$ のべき級数でなくて $x$ と $z$ のぺき級 数であらわすと，各項の示す変形を容易に理解できる ので， wを有限項で近似する場合の項のとり方につい て合理的に考えることができる. wを(7)式のように 与えると potential energy minimum の原理 $\delta \Pi=0$ は $\partial \Pi / \partial a_{m n}{ }^{*}=0$ と等価になる. との条件は 


$$
\begin{aligned}
\frac{\partial \Pi}{\partial a_{m n}{ }^{*}}= & \iint_{S} \frac{\partial}{\partial a_{m n} *}\left[\frac{D}{2}\left\{\left(\frac{\partial^{2} w}{\partial x^{2}}+\frac{\partial^{2} w}{\partial y^{2}}\right)^{2}-2(1-\nu)\left[\frac{\partial^{2} w}{\partial x^{2}} \frac{\partial^{2} w}{\partial y^{2}}-\left(\frac{\partial^{2} w}{\partial x \partial y}\right)^{2}\right]\right\}\right] d x d y \\
& +\iint_{S} \frac{\rho_{\infty} U^{2}}{2 M}\left[4+(\gamma+1) M \frac{\partial h^{*}}{\partial y}\right]\left[\frac{\partial w}{\partial y}+\frac{i \omega}{U} w\right] \frac{\partial w}{\partial a_{m n}{ }^{*}} d x d y \\
& -\iint \rho h^{*} \omega^{2} w \frac{\partial w}{\partial a_{m n}{ }^{*}} d x d y=0
\end{aligned}
$$

と表わされる.そこで

$$
\begin{array}{lll}
\xi=x / l, & \eta=y / l, & \zeta=z / l, \\
\beta=b^{*} / l, & \beta_{0}=b_{0}{ }^{*} / l, & \beta_{1}=b_{i}^{*} / l, \\
h=h^{*} / l, & h_{m}=h_{m}^{*} / l, & h_{0}=h_{0} / l, h_{1}=h_{i} * / l
\end{array}
$$

大翼厚で, $h_{0}^{*}, h_{l} *$ はその付け根および翼端での值を 表わす.)，また，

$$
a_{m n}=l^{m+n} \times a_{m n} *
$$

と表わして（8）式の計算を行なうと，つぎのような $\dot{a}_{r s}(r=0 \sim \infty, s=2 \sim \infty)$ を末知数とする連立方程式 が導かれる.

々無次元量で表わし（ここで $b_{0}{ }^{*}, b_{t}{ }^{*}$ はそれぞれ付り

根および翼端の翼弦長の $1 / 2, h_{m}{ }^{*}$ は各 $\xi$ 断面での最

$$
\begin{aligned}
\sum_{r=0}^{\infty} \sum_{s=2}^{\infty} a_{r s}\left(A_{m n r s}\right. & +C_{1} \cdot M\left(F_{m n r s}^{1 A}+M \cdot F_{m n r s}^{1 B}\right) \\
& +i C_{2} \cdot \omega\left(F_{m n r s}{ }^{2 A}+M \cdot F_{m n r s^{2 B}}{ }^{2 B}-C_{3} \omega^{2} D_{m n r s}\right]=0
\end{aligned}
$$

ここで

$$
\begin{aligned}
& \sum_{r=0}^{\infty} \sum_{s=2}^{\infty} a_{r s} A_{m n r s}=\frac{1}{2} \iint_{S}\left(\frac{h}{h_{0}}\right)^{3} \frac{\partial}{\partial a_{m n}}\left[\left(\frac{\partial^{2} w}{\partial \xi^{2}}+\frac{\partial^{2} w}{\partial \eta^{2}}\right)^{2}-2(1-\nu)\left\{\frac{\partial^{2} w}{\partial \xi^{2}} \frac{\partial^{2} w}{\partial \eta^{2}}-\left(\frac{\partial^{2} w}{\partial \xi \partial \eta}\right)^{2}\right\}\right] d \xi d \eta \\
& \sum_{r=0}^{\infty} \sum_{s=2}^{\infty} a_{r s} F_{m n r s}{ }^{1 A}=\frac{1}{2} \iint_{S} \frac{\partial w}{\partial \eta} \frac{\partial w}{\partial a_{m n}} d \xi d \eta, \sum_{r=0}^{\infty} \sum_{s=2}^{\infty} a_{r s} F_{m n r s}{ }^{1 B}=\frac{1}{2} \iint_{S} \frac{\partial h}{\partial \eta} \frac{\partial w}{\partial \eta} \frac{\partial w}{\partial a_{m n}} d \xi d \eta \\
& \sum_{r=0}^{\infty} \sum_{s=2}^{\infty} a_{r s} F_{m n r s} 2 A=\frac{1}{2} \iint_{S} w \frac{\partial w}{\partial a_{m n}} d \xi d \eta, \sum_{r=0}^{\infty} \sum_{s=2}^{\infty} a_{r s} F_{m n+s}{ }^{2 B}=\frac{1}{2} \iint_{S} \frac{\partial h}{\partial \eta} w \frac{\partial w}{\partial a_{m n}} d \xi d \eta \\
& \sum_{r=0}^{\infty} \sum_{s=2}^{\infty} a_{r s} D_{m n r s}=\iint_{S}\left(\frac{h}{h_{0}}\right) w \frac{\partial w}{\partial a_{m n}} d \xi d \eta \\
& C_{1}=\frac{4 \rho_{\infty} a_{\infty}^{2} l^{3}}{D_{0}}, C_{2}=\frac{4 \rho_{\infty} a_{\infty} l^{4}}{D_{0}}, C_{3}=\frac{\rho h_{0} * l^{4}}{D_{0}}
\end{aligned}
$$

$A_{\text {mnrs }}$ などの值は翼平面形のほかに板厚の分布が与え

翼断面形が第 2 図のような general double wedge 形:

られると数值積分により求めることができる. 本墖文

では下，翼の平面形は前後線が直線で：

$$
\beta / \beta_{0}=1-r_{\beta} \xi, \quad r_{\beta}=\left(\beta_{0}-\beta_{1}\right) / \beta_{0}
$$

最大翼厚 $h_{m}{ }^{*}$ のスパン方向の分布が直楾形で：

$h_{m} / h_{0}=1-r_{h} \xi, \quad r_{h}=\left(h_{0}-h_{1}\right) / h_{0}$

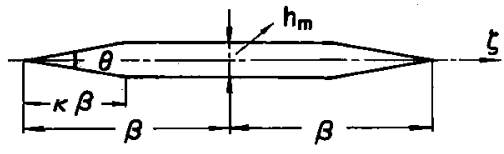

第2図翼断面

$$
\left.\begin{array}{lll}
-\beta \leq \zeta \leq-(1-\kappa) \beta & \text { では } & h / h_{m}=(\zeta+\beta) / \kappa \beta \\
-(1-\kappa) \beta \leq \zeta \leq(1-\kappa) & \text { では } & h / h_{m}=1 \\
(1-\kappa) \beta \leq \zeta \leq \beta & \text { では } & h / h_{m}=(-\zeta+\beta) / \kappa \beta
\end{array}\right\}
$$

の場合について示す. また楔の角度 $\theta$ がスパン方向に一定の場合を取报うととにすると

$$
\kappa=\frac{1-r_{k} \xi}{1-r_{\beta} \xi} \kappa_{0}
$$

となる. ここで $\kappa_{0}$ は付根断面での $\kappa$ の值である. (14)〜 (17) 式を用いて $A_{m n r s}$ などはつぎのようにあらわさ れる.

$$
\begin{aligned}
& A_{m n r s}=\int_{0}^{1} A_{\zeta} d \xi \\
& F_{m n r s}{ }^{1 A}=\int_{0}^{1} F_{\zeta}^{1 A} d \xi, \quad F_{m n r s}{ }^{1 B}=\int_{0}^{1} F_{\zeta}^{1 B} d \xi \\
& F_{m n r s}{ }^{2 A}=\int_{0}^{1} F_{\zeta}^{2 A} d \xi, \quad F_{m n r s^{2 B}}=\int_{0}^{1} F_{\zeta}{ }^{2 B} d \xi \\
& D_{m n r s}=\int_{0}^{1} D_{\zeta} d \xi
\end{aligned}
$$


ただし

$$
\begin{aligned}
& p=m+r, \quad K_{i}=(1-k)^{i}-1 \\
& a_{0}(\xi)=\{n(n-1) s(s-1)\} \xi^{n+s-4} \\
& a_{1}(\xi)=\{-2 k[n(n-1) r s+m n s(s-1)]\} \xi^{n+s-3} \\
& a_{2}(\xi)=\left\{\left(k^{2}+\nu\right)[m(m-1) s(s-1)+n(n-1) r(r-1)]+2\left(2 k^{2}+1-\nu\right) m n r s\right\} \xi^{n+s-2} \\
& a_{3}(\xi)=\left\{-2 k\left(k^{2}+1\right)[m(m-1) r s+m n r(r-1)]\right\} \xi^{n+s-1} \\
& a_{4}(\xi)=\left\{\left(k^{2}+1\right)^{2}[m(m-1) r(r-1)]\right\} \xi^{n+s}
\end{aligned}
$$

と記して

$$
\begin{aligned}
& \frac{1}{2} A_{\xi}=\left\{\frac{\beta^{p+1}}{p+1}\left(1+K_{p+1}\right)\left(1-r_{h} \xi\right)^{3}+\frac{\beta^{p+4}}{\left(\kappa_{0} \beta_{0}\right)^{3}}\left(\frac{K_{p+4}}{p+4}-\frac{3 K_{p+3}}{p+3}+\frac{3 K_{p+2}}{p+2}-\frac{K_{p+1}}{p+1}\right)\right\} a_{0} \\
& +\left\{\frac{\beta^{p-1}}{p-1}\left(1+K_{p-1}\right)\left(1-r_{h} \xi\right)^{3}+\frac{\beta^{p+2}}{\left(\kappa_{0} \beta_{0}\right)^{3}}\left(\frac{K_{p+2}}{p+2}-\frac{3 K_{p+1}}{p+1}+\frac{3 K_{p}}{p}-\frac{K_{p-1}}{p-1}\right)\right\} a_{2} \\
& +\left\{\frac{\beta^{p-3}}{p-3}\left(1+K_{p-3}\right)\left(1-r_{h} \xi\right)^{3}+\frac{\beta^{p}}{\left(\kappa_{0} \beta_{0}\right)^{3}}\left(\frac{K_{p}}{p}-\frac{3 K_{p-1}}{p-1}+\frac{3 K_{p-2}}{p-2}-\frac{K_{p-3}}{p-3}\right)\right\} a_{4} \cdots \cdots p: \text { 偶数 } \\
& \frac{1}{2} A_{\zeta}=\left\{\frac{\beta^{p}}{p}\left(1+K_{p}\right)\left(1-r_{h} \xi\right)^{3}+\frac{\beta^{p+3}}{\left(\kappa_{0} \beta_{0}\right)^{3}}\left(\frac{K_{p+3}}{p+3}-\frac{3 K_{p+2}}{p+2}+\frac{3 K_{p+1}}{p+1}-\frac{K_{p}}{p}\right)\right\} a_{1} \\
& +\left\{\frac{\beta^{p-2}}{p-2}\left(1+K_{p-2}\right)\left(1-r_{h} \xi\right)^{3}+\frac{\beta^{p+1}}{\left(\kappa_{0} \beta_{0}\right)^{3}}\left(\frac{K_{p+1}}{p+1}-\frac{3 K_{p}}{p}+\frac{3 K_{p-1}}{p-2}-\frac{K_{p-2}}{p-2}\right)\right\} a_{3} \cdots \cdots p \text { : 奇数 } \\
& F_{\zeta}^{1 A}=\left\{\begin{array}{l}
0 \\
\frac{r}{p} \xi^{n+s} \beta^{p}
\end{array}\right. \\
& \text { …..p: 偶数 } \\
& F_{\zeta}^{1 B}=\left\{\begin{array}{l}
\frac{(\gamma+1) h_{0}}{4 \kappa_{0} \beta_{0}} \frac{r}{p} \xi^{n+s} \beta^{p} K_{p} \\
0
\end{array}\right. \\
& \cdots \cdots p \text { : 奇数 } \\
& F_{\xi}^{2 A}=\left\{\begin{array}{l}
\frac{1}{p+1} \xi^{n+s} \beta^{p+1} \\
0
\end{array}\right. \\
& F_{\xi}^{2 B}=\left\{\begin{array}{l}
0 \\
\frac{(\gamma+1) h_{0}}{4 \kappa_{0} \beta_{0}} \frac{1}{p+1} \xi^{n+s} \beta^{p+1} K_{p+1}
\end{array}\right. \\
& D_{\zeta}=\left\{\begin{array}{l}
2 \xi^{n+s} \beta^{p+1}\left[\frac{\beta}{\kappa_{0} \beta_{0}}\left\{\frac{K_{p+2}}{p+2}-\frac{K_{p+1}}{p+1}\right\}+\frac{1-r_{h} \xi}{p+1}\left(1+K_{p+1}\right)\right] \\
0
\end{array}\right. \\
& \cdots \cdots p \text { : 偶数 } \\
& \cdots \cdots p \text { : 奇数 } \\
& \cdots \cdots p: \text { 偶数 } \\
& \cdots \cdots p \text { : 奇数 } \\
& \cdots \cdot \cdots p \text { : 偶数 } \\
& \cdots \cdots p \text { : 奇数 } \\
& \cdots \cdots p \text { : 偶数 } \\
& \cdots \cdot p \text { : 奇数 }
\end{aligned}
$$

以上により（18）式を SIMPSON の公式による数值皘 分で求めて $A_{m \pi r s}$ 等がきまる.

フラッター速度およびフラッター振動数は撓みを示 す（7）式のべき級数を有限項で打ち切って (11) 式 に示される複素数の固有値問題を解くことによって求 められる. すなわちちょうどフラッター速度では，山 は実数であるから，ての条件のもとに（11）式の $a_{r s}$ の係数の行列式 $=0$ ，すなわち

$$
\begin{aligned}
& \mid A_{m n r s}+C_{1} M\left(F_{m n r s}{ }^{A A}+M \cdot F_{m n r s}{ }^{1 B}\right) \\
& \quad+i C_{2} \omega\left(F_{m n r}{ }^{2 A}+M \cdot F_{m n r s}{ }^{2 B}\right) \\
& \quad-C_{3} \omega^{2} D_{m n r s} \mid=0
\end{aligned}
$$

したがって (21) 式左辺の実数部，虚数部を0ならし めるフラッターマッ八数 $M_{F}$ およびフラッター円振 動数 $\omega_{\boldsymbol{P}}$ を求めればよいととになる.

\section{3. 計算例および実験との比較}

実験結果と比較できるようにするため，航空宇宙技 術研究所で中井他によって行なわれた一連の実験の模

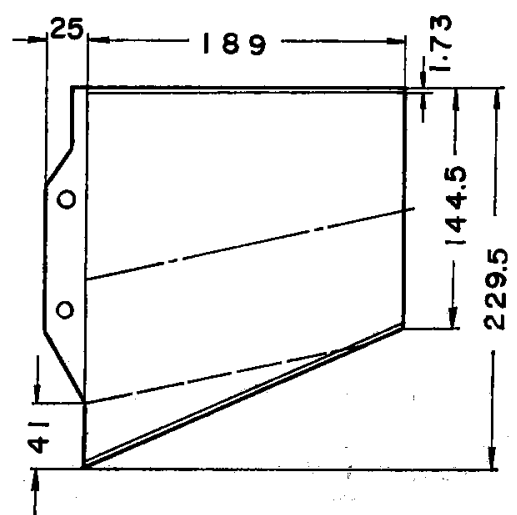

第 3 図 計算模型 (Model 85) 板厚 $2 \mathrm{~mm}$ ，図の単位 $\mathrm{mm}$ 
型のうちの一つ Model-85 を選び， その数值について 計算を行なった. 模型材料は純マグネシニウムで，そ の平面形および固定条件を第 3 図に示す. 数値は

$E=4.0 \times 10^{3} \mathrm{~kg} / \mathrm{mm}^{2}, \nu=0.33, \rho=1.775 \times 10^{-10}$ $\mathrm{kg} \cdot \mathrm{sec}^{2} / \mathrm{mm}^{4}, \quad l=187 \mathrm{~mm}, \quad 2 b_{0}^{*}=229.5 \mathrm{~mm}$,

$2 b_{l}^{*}=144.5 \mathrm{~mm}, h^{*}=2 \mathrm{~mm}$, 前後縁のウエッ ヂ幅 $=1.73 \mathrm{~mm}$

で, したがって

$k=0.22727, \beta_{0}=0.61364, \kappa_{0}=0.015094$

$h_{0}=0.010695, r_{\beta}=0.37037, r_{h}=0$
と計算される. この超音速風洞の測定部の動圧 $q$ $=\rho_{\infty} U_{\infty}^{2} / 2$ の筙囲は $0.8 \mathrm{~kg} / \mathrm{cm}^{2} な い し 1.5 \mathrm{~kg} / \mathrm{cm}^{2} の$ 箢囲である.したがって $\rho_{\infty} a_{\infty}^{2}$ こしては

$$
\begin{aligned}
& \rho_{\infty} a_{\infty}{ }^{2}=q /\left(M^{2} / 2\right) \\
& =\frac{\left[0.8 \mathrm{~kg} / \mathrm{cm}^{2} \sim 1.5 \mathrm{~kg} / \mathrm{cm}^{2}\right\rceil}{\left(M^{2} / 2\right)}
\end{aligned}
$$

の範囲の数值を用いなければならない. そこで $\rho_{\infty} a_{\infty}{ }^{2}$ の值として第 1 表に示す 4 通りの值の場合について計 算を行なった*.

撓み形としては

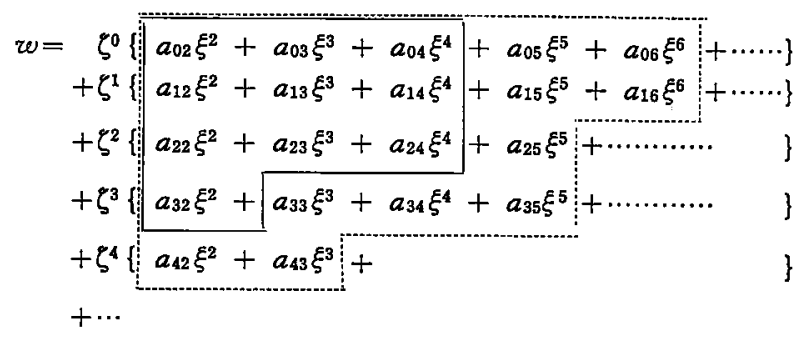

実線で囲んだような 10 項近似と点線で囲んだような 20 項近似との 2 通りの場合について計算を行なった。

数值計算に当たって（21）式における空気力による damping の項 $F_{m n s^{2}}$ による影響は小さいであろうこ とに着目して，まず，第 1 次近似ししてとの項を省略 した計算を行なった．との項を省略すると，(21)式の 各項は実数となる.したがって，フラッターマッハ数 $M_{B}$ はマッ八数 $M$ を与えた時の (21) 式の根 $\omega$ を求

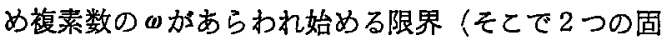
有振動数 $\omega_{A}$ 之 $\omega_{B}$ とが等しくなる）の $M$ の值とし て求められる ${ }^{13)}$. 第 4 図にこのような考えで計算した マッハ数と固有振動数の関係を示す.との計算結果加 ら求めたフラッターマッハ数 $M_{F}$ およびフラッタ一振 動数 $f_{F}$ を第 1 表に示した.

第 1 表には, 中井他の実験結果と比較するため stiff-

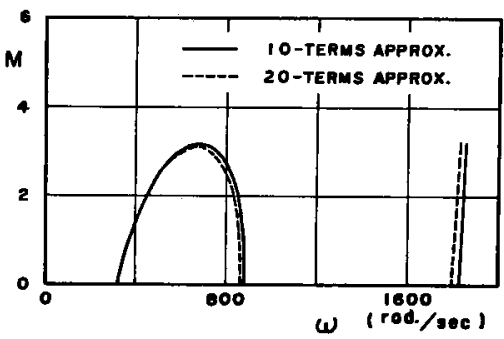

第 4 図 固有円振動数之 Mach 数の関係 Model 85, $\rho_{\infty} a^{2}{ }_{\infty}=3.334 \times 10^{-s}$ $\mathrm{kg} / \mathrm{mm}^{2}$ の場合

ness-altitude-parameter $\left(b_{0}^{*} \omega_{2} / a_{\infty}\right) \sqrt{\mu}$ の值を計算 してあるが, これは,

$$
\mu=\frac{\text { 翼の全質量 }}{\pi \rho_{\infty} \int_{0}^{l} b^{* 2} d x} \text { （質量比） }
$$

\begin{tabular}{|c|c|c|c|c|c|c|c|}
\hline & \multirow{2}{*}{$\begin{array}{c}\rho_{\infty} a_{\infty}^{2} \\
\left(\times 10^{-8} \mathrm{~kg} / \mathrm{mm}^{2}\right)\end{array}$} & \multicolumn{2}{|c|}{$\frac{b_{0}^{*} \omega_{2}}{a_{\infty}} \sqrt{\mu}$} & \multicolumn{2}{|c|}{$M_{F}$} & \multicolumn{2}{|c|}{$\begin{array}{c}f_{k} \\
(\mathrm{cps})\end{array}$} \\
\hline & & 10 項 & 20 項 & 10 項 & 20 項 & 10 項 & 20 項 \\
\hline \multirow{5}{*}{ Model 85} & 1.688 & 3.770 & 3.728 & 5.570 & 5.416 & 105.5 & 103.9 \\
\hline & 2.615 & 3.029 & 2.995 & 3.905 & 3. 789 & 107.8 & 106.0 \\
\hline & 2.785 & 2.934 & 2.901 & 3.703 & 3.590 & 108.1 & 106.3 \\
\hline & 3.334 & 2. 683 & 2.653 & 3. 183 & 3.084 & 108.8 & 107.0 \\
\hline & 7.357 & 1.806 & 1.786 & 1.578 & 1.524 & 111.5 & 109.5 \\
\hline \multirow{4}{*}{ Model 90} & 1.688 & 3.461 & 3.422 & 4. 914 & 4. 772 & 95.13 & 93.66 \\
\hline & 2.615 & 2.781 & 2. 750 & 3.414 & 3. 308 & 97.02 & 95.39 \\
\hline & 3. 334 & 2.463 & 2. 435 & 2. 768 & 2. 679 & 97.85 & 96.20 \\
\hline & 7.357 & 1.658 & 1. 639 & 1.355 & 1.307 & 99.82 & 98.13 \\
\hline
\end{tabular}

第1表 $M_{\boldsymbol{F}}$ および $f_{\boldsymbol{F}}$

*空気中を飛行する婸合，海面上での值は $\rho_{\infty} a_{\infty}^{2}=1.445 \times 10^{-8} \mathrm{~kg} / \mathrm{mm}^{2}$. 高度 1 万米では $\rho_{\infty} a_{\infty}^{2}=3.789 \times 10^{-\mathrm{s}} \mathrm{kg} / \mathrm{mm}^{2}$ である. 


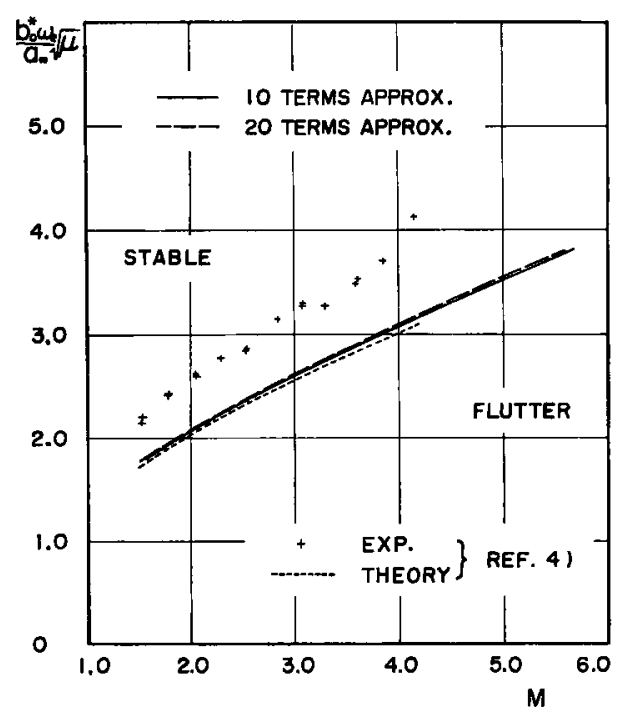

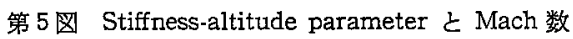
の関係，理論值と実験值

$\omega_{2}: 2$ 次の固有円振動数（掘り 1 次） として,

$$
\begin{aligned}
\frac{b_{0}{ }^{*} \omega_{2}}{a_{\infty}} \sqrt{\mu}= & {\left[\frac{b_{0} * \omega_{2} \times V \overline{(\text { 翼の全質量 })}}{\sqrt{\pi \int_{0}^{l} b^{* 2} d x}}\right] } \\
& \times \frac{1}{\sqrt{\rho_{\infty} a_{\infty}^{2}}}
\end{aligned}
$$

こあらわされ， $\rho_{\infty} a_{\infty}^{2}$ の值から求められる. また第 1 表には別の実験模型 Model-90 についての計算結果も 付記した. この結果加ら導加れる $\left(b_{0}{ }^{*} \omega_{2} / a_{\infty}\right) \sqrt{\mu}$ と $M_{P}$ との関係を第 5 図に示した. 第 5 図は Model-85 の結果を示しているが，Model-90 の結果もと扎とほ ぼ同一である。第 5 図には中井他の実験値捛よび中井 ほかか Model-90について従来の計算法により 3 自由 度のフラッター問題として求めた理論值を併せて記し た. 本計算法による值の 10 項近似と 20 項近似との 差はごくわずかである，したがって項の数はほほ十分 であると考えられる．また本計算法による值は従来の 計算法による值とくらへていずか実験值に近い程度で 大差ない，したがって中井ほかが 3 次の固有振動モー ドまでを用いて計算したのは，使用モード数としてほ 隹妥当であると考えられる.

実験とは傾向は良く一致しているが数值的には計算 值の方が約 20\% 位低く出ている，とれでは, 計算でフ ラッターが起きないととを保証した stiffness-altitudeparameter でフラッターが起きるととになり，危険で ある. 第 5 図に示した中井ほかの実験点は，(19)式に 示したように風洞の動圧の可変箖国に限度があるた め，第 3 図に示した模型だけでなく，板厚は同じで平

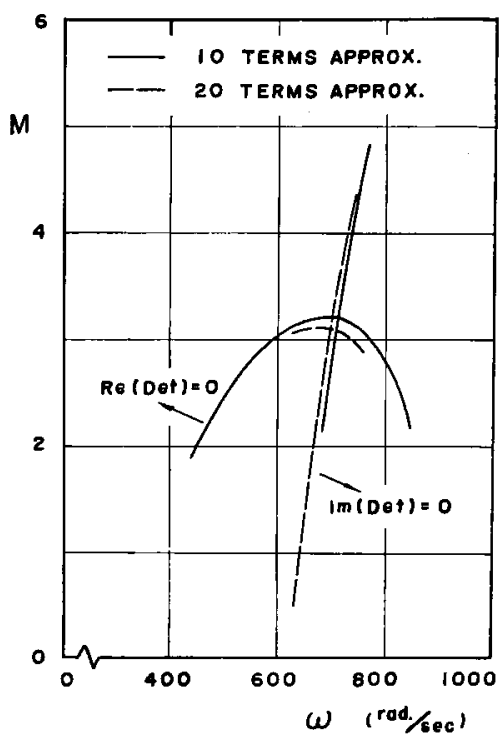

第6図複素固有值問題に括りる Flutter Point の决定 Model $85, \rho_{\infty} a_{\infty}{ }^{2}=3.334 \times 10^{-2} \mathrm{~kg} / \mathrm{mm}^{2}$, $a_{\infty}=242.1 \mathrm{~m} / \mathrm{sec}$ の場合

面形を相似形に変えた 5 種類の模型についての測定結 果である. 固定金具の寸法は同一なので，固定部の長 さの比率が異なっている，レたがって実験值をMode1 85 および Model-90 だけについての計算值と比較す るのでは不完全であるが，計算值が害験値とこの程度 兞うという大勢には変わりない.

\section{4. 空力的減衰項の影響}

空気力の減衰項を省略しないで (21) 式の複素数の固 有值問題としての計算は，第 6 図に示すように，(21) 式の実数部 $=0$ を示す曲線と，(21) 式の虚数部 $=0$ を 示す曲線との交点として求められる. との計算に当た って，風洞実験を対象にした場合は，係数 $C_{2}$ の中の $\rho_{\infty} a_{\infty}\left(=\rho_{\infty} a_{\infty}^{2} \div a_{\infty}\right)$ すなわち $a_{\infty}$ の值をどう扱うか という問題が新たに生ずる，超音速風洞では，一次元 等エントロピー流の関係式を用いると，貯気漕温度を $T^{\circ} \mathrm{K}$, 気体常数を $R$, 空気の比熱の比 $\gamma=1.4$ と記し て，測定断面での音速は

$$
a_{\infty}=\frac{1}{\sqrt{f(M)}}, \quad f(M)=\frac{1+0.2 M^{2}}{1.4 R T}
$$

と表わされ，さらに（22）式と（25）式とから

$$
a_{\infty}=\sqrt{\frac{1.4 R T}{1+0.4 q /\left(\rho_{\infty} a_{\infty}^{2}\right)}}
$$

亡 $q$ と $\rho_{\infty} a_{\infty}^{2}$ の関係として表わされることが導かれ る. そこで $q$ として適当な值を選ぶこととし，そのた め中井ほかの実験点の $a_{\infty}$ と $\rho_{\infty} a_{\infty}^{2}$ との関係をプロ ットしてみると第 7 図のようになる.そとで各 $\rho_{\infty} a_{\infty}{ }^{2}$ の值に対して代表点として $A_{0}, B_{0}, C_{0}, D_{0}$ 点をとっ 
板翼の超音速フラッター速度の一計算法 (名取通弘，小林繁夫）

第 2 表 $M_{F}$ および $f_{F}$ ，空力的ダンピングの影㗽（Model 85 の場合）

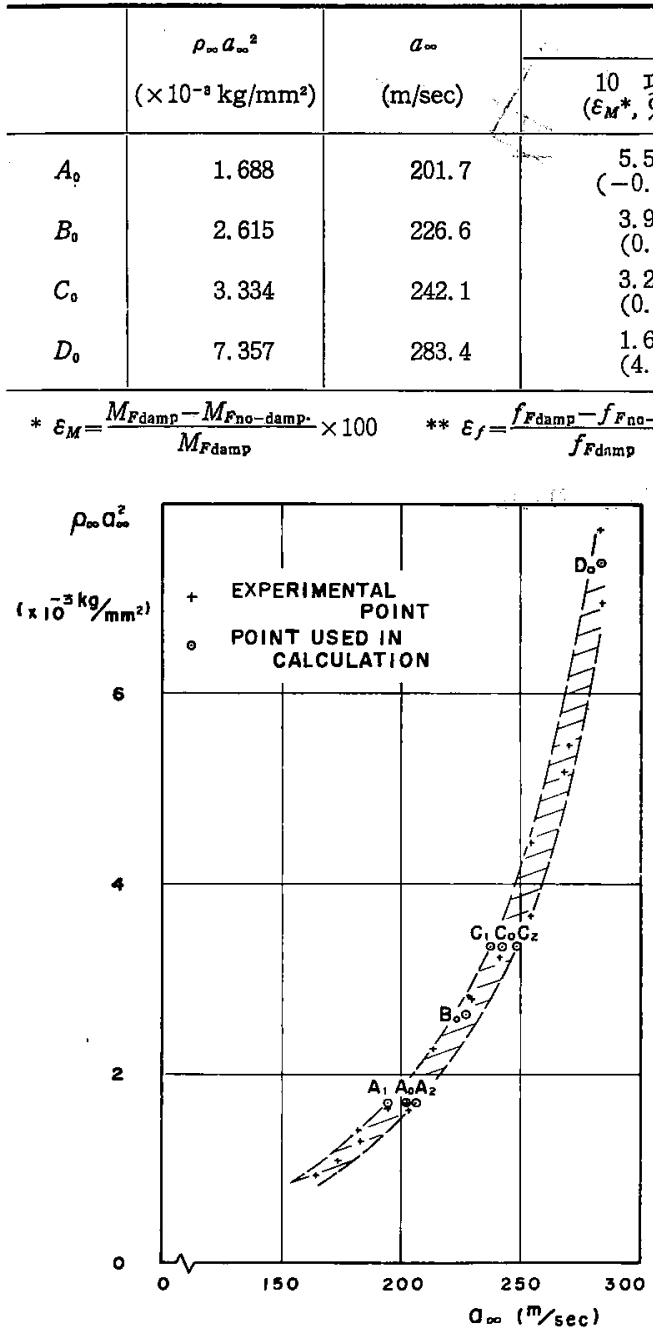

第 7 図 風胴実験 Ref. 4) における $a_{\infty}$ と $\rho_{\infty} a_{\infty}^{2}$ の関係

第3表 $M_{F}$ および $f_{F}, a_{\infty}$ の影然 (Model 85 の場合)

\begin{tabular}{c|c|c|c|c}
\hline & $\begin{array}{c}\rho_{\infty} a_{\mathrm{o}^{2}}^{2} \\
\left(\times 10^{-8}\right. \\
\left.\mathrm{kg} / \mathrm{mm}^{2}\right)\end{array}$ & $\begin{array}{c}a_{\infty} \\
(\mathrm{m} / \mathrm{sec})\end{array}$ & $M_{F}$ & $\begin{array}{c}f_{F} \\
(\mathrm{cps})\end{array}$ \\
\hline$A_{1}$ & & 194.0 & 5.395 & 109.3 \\
$A_{0}$ & 1.688 & 201.7 & 5.393 & 109.3 \\
$A_{2}$ & & 206.0 & 5.392 & 109.3 \\
\hline$C_{1}$ & & 237.0 & 3.115 & 110.5 \\
$C_{0}$ & 3.334 & 242.1 & 3.114 & 110.5 \\
$C_{2}$ & & 248.0 & 3.112 & 110.5 \\
\hline
\end{tabular}

て計算した．その結果を第 2 表に示した，さらに同一 の $\rho_{\infty} a_{\infty}^{2}$ の值に対し $a_{\infty}$ の值が変わった限界の場合 として $A_{1}, A_{2}, C_{1}, C_{2}$ 点についての計算結果を第 3 表 に示したか，第3表注 $a_{\infty}$ の值のとり方による $M_{F}$ ， $f_{F}$ の差は極めて小さいととを示している.したがっ て第 2 表の結果は罗当であることが結諭される．第 2

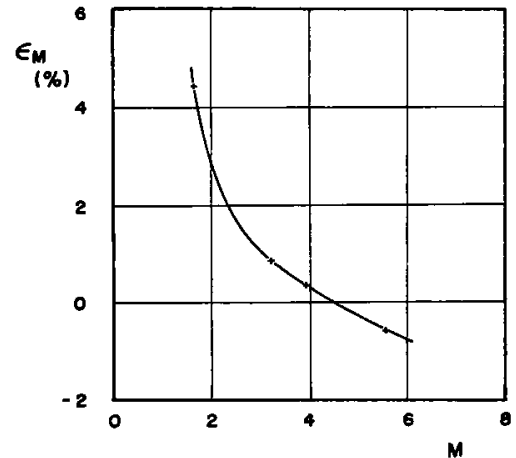

第8図 フラッターマッ八数に対する空力的隇衰頂の影 製, Model 85, 10 項近似の場合

表に記した $\varepsilon_{M}, \varepsilon_{r}$ は, 空力的減衰項を考慮しないで求 めた值が，考慮して求めた值にくらへててどれだけの差 があるかを示したあので，さらにての $\varepsilon_{M}$ とマッ八数 との関係を第 8 図传示した. この図から piston theory が有効とされるマッハ $3 \sim 4$ で空力的減衰項の影響は 非常に小さく，無視し得るととが結諭される。この場合 $\varepsilon_{M}$ が正ならば减衰项の省略は安全側の計算というこ とになる．しかし第 8 図は $M>4.5$ で $\varepsilon_{M}$ が真である 事を示している、減衰項を省略したととが安全側の計 算とは限らないというととは注目すべき結果である.

\section{5. 部分固定の影響}

第3 節で述べたように航技研で行なわれた䒠験模型 は $x=0$ 断面の一部は固定されていない. したがって $x=0$ で全部固定とした第 2 節の解析法による結果と 比䩙するのは不十分である. 実験值之計算值との相違 はとの事に基因するかも知れないというととと，実際 の翼でこのような固定条件のあのああり得るというと とで, 第 2 節の計算法を部分固定の場合に拡張しょう.

第 9 図のような部分固定の境界条件に対応して撓み 形を

$$
w=\sum_{m=0}^{\infty} \sum_{n=2}^{\infty} a_{m n} * z^{m} x^{n}+w_{a}(x, z)
$$




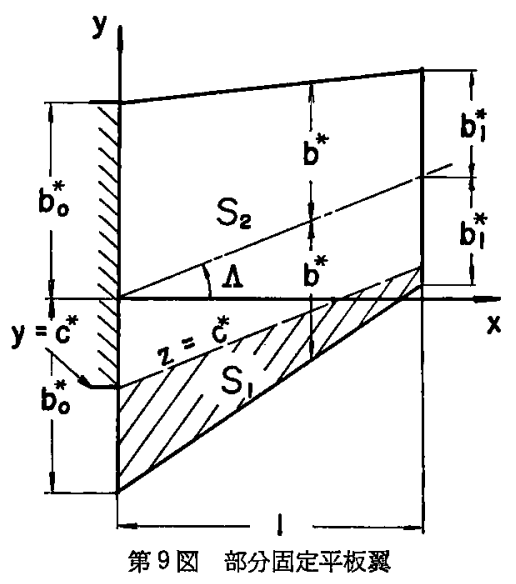

$S_{1}$ 領域;

$$
w_{a}(x, z)=\sum_{m=0}^{\infty} a_{m 0} *^{m}+x \sum_{m=0}^{\infty} a_{m 1} * z^{m}
$$

$S_{2}$ 領域;

$$
w_{a}(x, z)=0
$$

と仮定する. ここで $S_{1}$ 領域と $S_{2}$ 領域の境界 $z=c^{*}$ なる直線上で, 板の変位お゙よ゙傾斜の連続の条件から

$$
z=c^{*} ; w_{a}=0, \frac{\partial w_{a}}{\partial x}=0, \frac{\partial w_{a}}{\partial y}=0
$$

が成立たなければならない（28-1）式を（29）式に代 スして，xのいかにかかわらず成り立つための条件之 $\iota \tau$

$$
\begin{aligned}
& \sum_{m=0}^{\infty} a_{m 0} * c^{* m}=0, \quad \sum_{m=0}^{\infty} a_{m 2} * c^{* m}=0 \\
& \sum_{m=1}^{\infty} a_{m 0} * m c^{* m-1}=0, \\
& \sum_{m=1}^{\infty} a_{m 1} * m c^{* m-1}=0
\end{aligned}
$$

が導か机る.つまり $a_{m 0}{ }^{*}, a_{m 1} *$ は全く任意ではなく との4つの条件を満たさなければならず，したがって 末知量の数は 4 つ減少することになる.

第 2 節と同様の計算を行なうことによりフラッター

$$
\left.\begin{array}{l}
b_{0}(\xi)=\left[2 k \mu_{r s}\{n s(n-1) r\}\right] \xi^{n+s-3} \\
b_{1}(\xi)=\left[-2\left(2 k^{2}+1-\nu\right) \mu_{r}\{m n r s\}\right] \xi^{n+s-2} \\
b_{2}(\xi)=\left[2 k\left(1+k^{2}\right) \mu_{r s}\{m r s(m-1)\}\right] \xi^{n+s-1} \\
c_{0}(\xi)=\left[2 k \mu_{m n}\{n s(s-1) m\}\right] \xi^{n+s-3} \\
c_{1}(\xi)=\left[-2\left(2 k^{2}+1-\nu\right) \mu_{m n}(m n r s)\right] \xi^{n+s-2} \\
c_{2}(\xi)=\left[2 k\left(1+k^{2}\right) \mu_{m n}\{m r n(r-1)\}\right] \xi^{n+s-1} \\
d_{1}(\xi)=\left[2\left(2 k^{2}+1-\nu\right) \mu_{m n} \mu_{r s}\{m n r s\}\right] \xi^{n+s-2}
\end{array}\right\}
$$

ここで

$$
\left\{\begin{array}{lrl}
p=2, & q=0,1 ; \mu_{p q}=c \\
p=3, & q=0,1 ; \mu_{p q}=c^{2} \\
q \geq 2 & ; \mu_{p q}=0
\end{array}\right.
$$

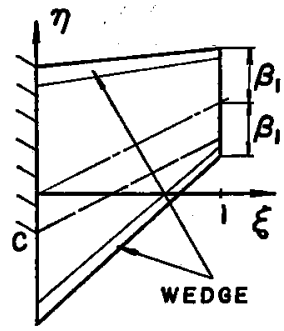

(a) $|c| \leqq \beta_{1}$

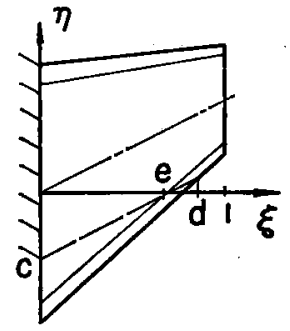

(b) $|c|>\beta_{1}$

$$
\begin{aligned}
& d= \frac{c+\beta_{0}}{\beta_{0} r_{\beta}}, e=\frac{c / \beta_{0}+1-n_{0}}{r_{A}-r_{A} n_{0}} \\
& \text { 第 } 10 \text { 図 部分固定平板淇 }
\end{aligned}
$$

行列式(21) 式に到達するが，との場合の $A_{m n r s}$ などの 計算式は, ことでは $w_{a}$ として

$$
w_{a}=\sum_{r=0}^{3} a_{r 0} \zeta^{r}+\xi \cdot \sum_{r=0}^{3} a_{r 1} \zeta^{r}
$$

を用いた場合について示す. 8 個の未定係数は (30) 式 の条件を用いてつきの 4 個にまとめられる.

$$
\begin{aligned}
w_{a}= & (\zeta-c)^{2} a_{20}+(\zeta-c)^{2}(\zeta+2 c) a_{30} \\
& +\xi\left[(\zeta-c)^{2} a_{21}+(\zeta-c)^{2}(\zeta+2 c) a_{31}\right]
\end{aligned}
$$

ここで $c=c^{*} / l$

$A_{m n r s}$ などの計算式はつぎのようになる.

$$
\begin{aligned}
& A_{m n r s}=\int_{0}^{u} A_{\zeta} d \xi \\
& F_{m n r s}{ }^{1 A}=\int_{0}^{u} F_{\zeta}^{1 A} d \xi, \quad F_{m n r s}^{1 B}=\int_{0}^{u} F_{\zeta}^{1 B} d \xi \\
& F_{m n r s}{ }^{2 A}=\int_{0}^{u} F_{\zeta}^{2 A} d \xi, \quad F_{m n r s}^{2 B}=\int_{0}^{u} F_{\zeta}^{2 B} d \xi \\
& D_{m n r s}=\int_{0}^{u} D_{\zeta} d \xi
\end{aligned}
$$

ここで上限 $u$ は第 10 図に示すように $z=c^{*}$ 線が前綅 を切るか切らないかによって

$$
\left\{\begin{array}{l}
|c| \leq \beta_{1} ; u=1 \\
|c|>\beta_{1} ; u=d \equiv\left(c+\beta_{0}\right) / \beta_{0} r_{\beta}
\end{array}\right.
$$

である. $A_{6}$ などは $(19)$ 式の $a_{0}(\xi)$ などのほかに 


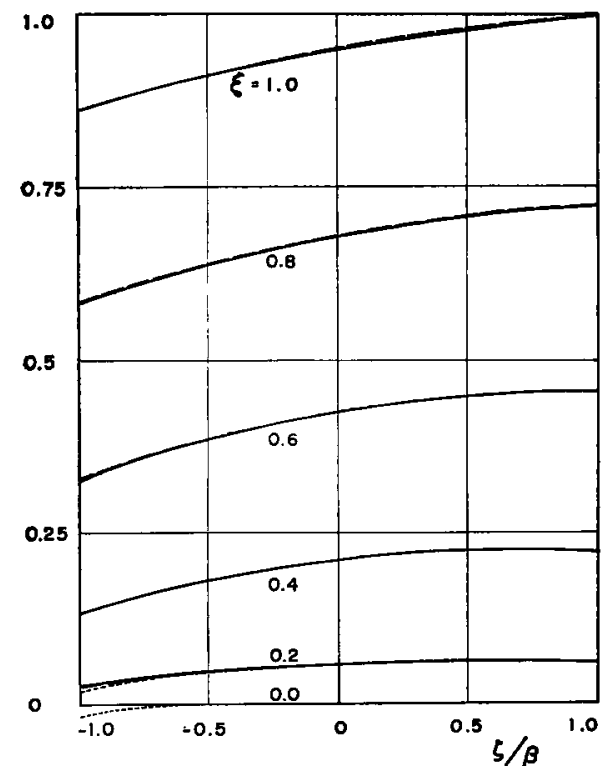
(a) 1 次掁動 10 項近仙
20 項近似
$45.42 \mathrm{cps}$
部分固定 14 項近似
45. 31
45. 32

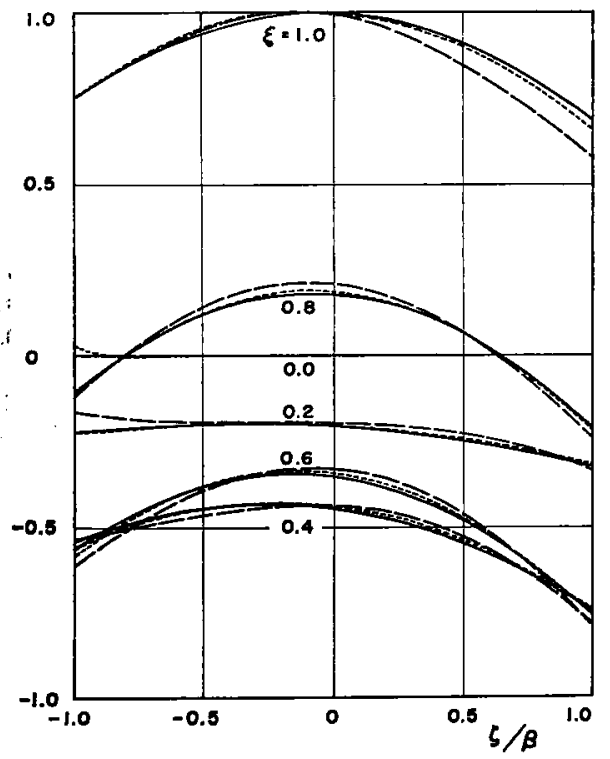

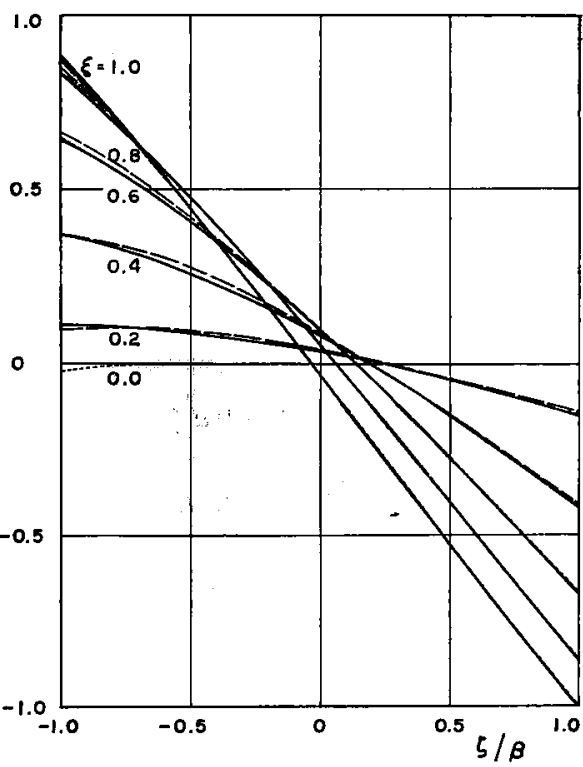
(b) 2 次振動 10 項近似
20 項近做
$124.9 \mathrm{cps}$
部分固定 14 項近似
123.5
124.5

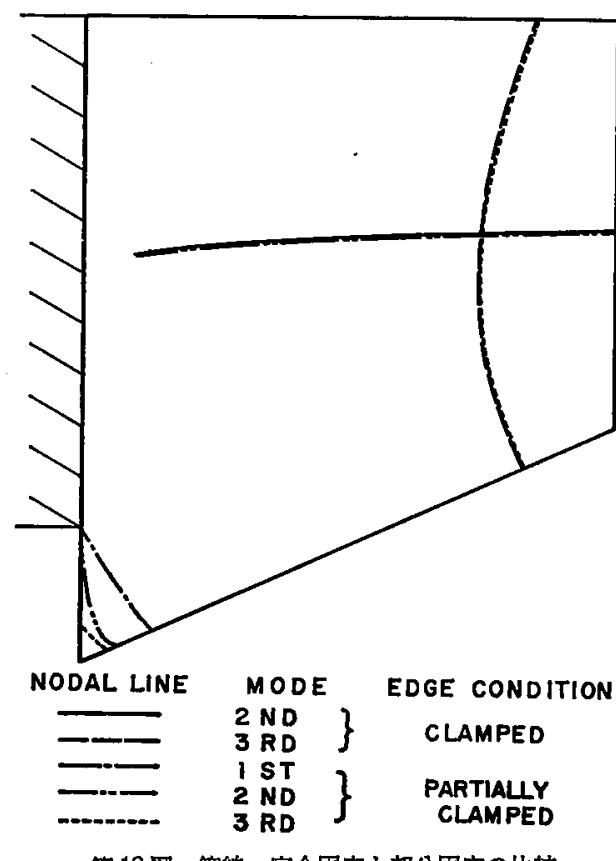

第 12 困節線, 完全固定と部分固定の比較

第11図 翼弦の正規化变位，Model 90 の場合

実線：10 項近似完全固定

破楾：20 項近做完全固定

点線：14 項近似部分固定 


$$
\begin{aligned}
A_{\zeta}= & \int_{-\beta}^{v}\left(\frac{h}{h_{0}}\right)^{3}\left\{\left\{a_{0} \zeta^{m+r}+a_{1} \zeta^{m+r-1}\right.\right. \\
& \left.+a_{2} \zeta^{m+r-2}+a_{3} \zeta^{m+r-3}+a_{4} \zeta^{m+r-4}\right\} \\
& +\left\{b_{0} \zeta^{m}+b_{1} \zeta^{m-1}+b_{2} \zeta^{m-2}\right\} \\
& \left.+\left\{c_{0} \zeta^{r}+c_{1} \zeta^{r-1}+c_{2} \zeta^{r-2}\right\}+d_{1}\right] d \zeta \\
F_{\zeta}^{1 A}= & \frac{1}{2} \int_{-\beta}^{v} r\left(\zeta^{r-1}-\mu_{r s}\right) f_{m n} \xi^{n+s} d \zeta \\
F_{\zeta}^{1 B}= & \frac{1}{2} \frac{\gamma+1}{4} \int_{-\beta}^{v} \frac{\partial h}{\partial \eta} r\left(\zeta^{r-1}-\mu_{r s}\right) f_{m n} \xi^{n+s} d \zeta \\
F_{\zeta}^{2 A}= & \frac{1}{2} \int_{-\beta}^{v} f_{m n} f_{r s} \xi^{n+s} d \zeta \\
F_{\zeta}^{2 B}= & \frac{1}{2} \frac{\gamma+1}{4} \int_{-\beta}^{v} \frac{\partial h}{\partial \eta} f_{m n} f_{r s} \xi^{n+s} d \zeta \\
D_{\zeta}= & \int_{-\beta}^{v} \frac{h}{h_{0}} f_{m n} f_{r s} \xi^{n+s} d \zeta
\end{aligned}
$$

ここで

$$
\begin{aligned}
& q \geq 2 ; \quad f_{p q}=\zeta^{p} \\
& p=2, q=0,1 \\
& \left\{\begin{array}{l}
S_{1} \text { 領域; } f_{p q}=(\zeta-c)^{2} \\
S_{2} \text { 領域; } f_{p q}=0
\end{array}\right. \\
& p=3, q=0,1 \\
& \left\{\begin{array}{l}
S_{1} \text { 領域; } f_{p q}=(\zeta-c)^{2}(\zeta+2 c) \\
S_{2} \text { 領域; } f_{p q}=0
\end{array}\right\}
\end{aligned}
$$

積分の上限 $v$ は

$$
v=\left\{\begin{aligned}
c: & (m=2, n=0,1, r, s \text { 任意 }) \\
& (m=3, n=0,1, r, s \text { 任意 }) \\
& (r=2, s=0,1, m, n \text { 任意 }) \\
& (r=3, s=0,1, m, n \text { 任意 }) \\
\beta: & n, s \text { 共 } \text { 以 } 2 \text { 以上の場合 }
\end{aligned}\right.
$$

ここで $n$ および $s$ がともに 2 以上の場合の $A_{\zeta}, F_{\xi}^{1.4}$, $F_{\zeta}{ }^{1 B}, F_{\zeta}{ }^{2 A}, F_{\zeta}{ }^{2 B}, D_{\zeta}$ は(20)式に示したあのと同じで ある. それ以外の 8 つの場合だけ $h$ の分布 (16) 式を (37)式に代入して求められる.

前節で空力的減衰項の影響が小さいことが明らかに されたので，部分固定の影響を数值許算するに当たつ $\tau$, 空力的減衰項を省略して, 実数の固有値問題とし

第 4 表 部分固定の影暗

14 項近促，空力的ダンピング項省略

\begin{tabular}{c|c|c|c|c}
\hline & $\begin{array}{c}\rho_{\infty} a_{\infty}^{2} \\
\left(\times 10^{-3}\right. \\
\left.\mathrm{kg} / \mathrm{mm}^{2}\right)\end{array}$ & $\frac{b_{0}^{*} \omega_{2}}{a_{\infty}} \sqrt{\mu}$ & $M_{F}$ & $\begin{array}{c}f_{F} \\
(\mathrm{cps})\end{array}$ \\
\hline \multirow{3}{*}{ Mode1 85 } & 1.688 & 3.758 & 5.516 & 104.7 \\
& 2.615 & 3.020 & 3.866 & 106.9 \\
& 3.334 & 2.675 & 3.149 & 108.1 \\
& 7.357 & 1.801 & 1.561 & 110.6 \\
\hline \multirow{3}{*}{ Model 90 } & 1.688 & 3.450 & 4.846 & 94.57 \\
& 2.615 & 2.772 & 3.364 & 96.37 \\
& 3.334 & 2.455 & 2.726 & 97.21 \\
& 7.357 & 1.653 & 1.333 & 99.22 \\
\hline
\end{tabular}

て計算した．計算結果を第 4 表に示した。この結果を プロットすると，第 5 図の完全固定の計算結果とほと んど同一で，わずかに実験值側である.この程度の部 分固定ではその影響が非常に小さいととが明らがさ れたすのと考えられる．との理由を理解する助けとし て振動モードがどの程度変わるかの計算結果を第 11 図，第 12 図に示した。とれらの図から，部分固定の 影響は固定されない部分にのみあらわれているにすき ないことがわかる.すなわち振動モード，振動数とす にあまり影響を受りていないからフラッター速度も余 り変わらないと考えられる.

\section{6. 結 論}

板翼の超音速フラッター速度を，固有振動モードに 関する知識なしに直接求める方法を提案し，従来の計 算法による計算值や実験值と比較した結果，てのよう な計算法が十分実用性をもつことが示されたすのと考 えられる. 本論文では板翼について示したが，てのよ うな計算方法は構造翼にす適用することができる。実 験值と計算值との差は，本論文では追求しなかつた空 気力として piston theoryを用いたととによるものよ 考えられる.今後の課題として，計算精度を高めるた めには空気力の取り报いについて検討しなりればなら ない.

本研究を御指導いただいた林毅教授に厚く感謝の意 を表します。

\section{参考文献}

1) H. Ashley and G. Zartarian: Piston Theory-A New Aerodynamic Tool for the Aeroelastician. J. A. S., Vol. 23, No. 12, pp. 1109-1118 (1956-12).

2) H.G. Morgan, H. L. Runyan and V. Huckez: Theoretical Considerations of Flutter at High Mach Numbers. J. A.S., Vol. 25, No. 6, pp. 371381 (1958-6).

3) H. G. Morgan, V. Hucket. and H. L. Runyan: Procedure for Calculating Flutter at High Supersonic Speed Including Camber Deflections and Comparison with Experimental Results. NACA TN-4335 (1958-9).

4) E. NakaI, T. Takagi, K. Isogat and T. Morita: Experimental and Calculated Results of Supersonic Flutter Characteristics of a Low-AspectRatio Flat-Plate Surface. NAL TR-125T (1967-1).

5) E.C. YAtes Jr.: Subsonic and Supersonic Flutter Analysis of a Highly Tapered Swept-Wing Planform Including Effects of Density Variation and Comparison with Experiments. NASA TN-4230 (1967-11).

6) R.L. Bisplinghoff and J. Dugungi: Influence of Aerodynamic Heating on Aeroelastic Phenomena. High Temperature Effects in Aircraft Structures. AGARDograph No. 28, Chapter 14, pp. 288-312 (1958). 
7) H.L. Runyan and N.H. Jones: Effects of Aerodynamic Heating on the Flutter of a Rectangular Wing at a Mach Number of 2. NASA TN D-460 (1960-6).

8) J. M. Grozn and R. Rosecrans: Effect of Aerodynamic Heating on the Flutter of a Thin FlatPlate Arrow Wing. NASA TN D-1788 (1963-5).

9) S. Kobayash: Flutter of Wings Subjected to Aerodynamic Heating. Trans. of Japan Society for Aeronautical and Space Science, Vol. 5, No. 7 (1962-7).

10）林 邦夫，小林繁夫：後退板翼の固有振動の一解析法 第 5 回蘗造強度に関する請演会講演集 (1963).

11) C.E. Watkins and J.H. Berman: On the Kernel
Function of the Integral Equation Relating Lift and Down-wash Distributions of Oscillating wings in Supersonic Flow. NACA TN-3438 (1955-5).

12) M. T. Landahl and V.J.E. Stark: Numerical Lifting Surface Theory-Problems and Progress. AIAA J., Vol. 6, No. 11, pp. 2049-2060 (1968-11).

13) J. M. Hedgepeth: Flutter of Rectangular Simply Supported Panels at High Supersonic Speeds. J. A. S., Vol. 24, No. 8, pp. 563-573 (1957-8).

14）川井忠彦，塙 武敏，戸川隼人，高橋利之，越出慎一： 平板翼の振動认ついて，NAL TR-30 (1962-10).

15）中井暎一，森田甫之：平板翼模型の固有振動モードの 測定, NAL TM-104 (1967-4).

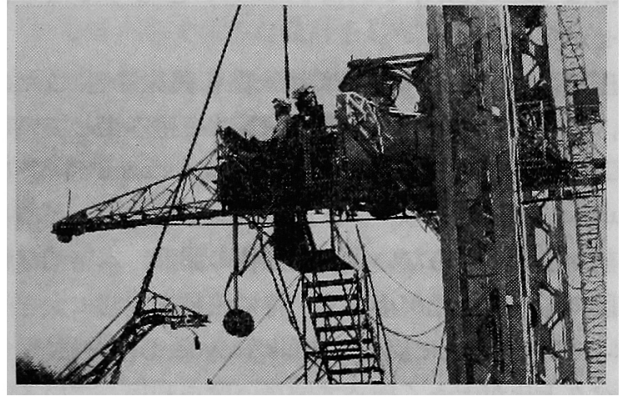

表紙写真説明

VTOL 機の垂直離着陸およびホバリング飛行を研 究するためのフライング・テスト・ベッド（全辰 $10 \mathrm{~m}$,
全幅 $7 \mathrm{~m}$, 全高 $3 \mathrm{~m}$, 全備重量約 $2,200 \mathrm{~kg}$, 乗員 1 名, エンジン JR $100 \mathrm{~F} 2$ 基) は昭和 44 年 11 月 21 日 加ら29日に加けて，宮城県にある角田支所において， はじめて有人飛行を行ない，高度制御実験に成功し た.

機体は 2 本のガイド・レールに沿って上昇下降させ， 高度制御はエンジンの推力で行ない，また加速度制御 を主体とする三重系自動安定装置を装備した。

実験は整備ならびに慣熟運転を 23 回行なった後， 上昇降下実験を 7 回行なった。最大高度 $2.15 \mathrm{~m}$ ，最 大上昇速度 $0.3 \mathrm{~m} / \mathrm{s}$, 最大下降速度 $0.5 \mathrm{~m} / \mathrm{s}$, 平均帯 空時間約 2 分 25 秒であった.

(滝沢直人)

\section{微小焦点 $\mathbf{X}$ 線回析ならびに細束 $\mathbf{X}$ 線 回析技術に関る講習会}

主催：日本材料学会

協賛(予定)：日本機械学会，日本金属学会，日本鉄鋼 協会, 日本非破壊検查協会, 溶接学会, 高分子 学会, 応用物理学会, 精機学会, 日本造船学会, 日本航空宇宙学会

期日：昭和 45 年 5 月 30 日（土） 6 月 2 日（火） 4 日間 会場：京都工業会館

京都市右京区西京極町の坪町（西大路五条西入 ル下ル） TEL. 075-(313)-0751（代表）

\section{計画書}

社団法人 日本材料学会

1. 国際会議の名称

和文名 材料の力学的挙動代関する国際会議 (略称：材料国際会議)

欧文名 International Conference on Mechanical Behavior of Material

(略称：ICM)
2. 開催期日

昭和 46 年 8 月 15 日 20日 (金)

3. 開催場所

国立京都国際会館（京都市左京区宝ヶ池）

4. 計画の概要

材料の巨視的力学的な挙動と化学構造や微視的 举動との関連についての研究成果の報告および 討諭を目的とする。

5. 予想される規模 予定参加国 日本はか，20数ヶ国

6. 主催・協替およ゙後嗳 主催 日本材料学会 協賛学協会, 化学工，火力発雪技術，高分子瀻 維, 土木, 化学, 化学䋊維, 機械, 金属, 建筑, 航空宇宙，鋼䉓造，ゴム、ゴム工業，造船，鉄

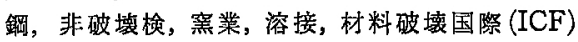
その他.

後援 (予定) 日本学術会議

7. 組 織

組織委員会委員長

害行委員会委員㢀 広田寿一（日本材料学会会長）

平 修二（京都大学教授） 